\title{
Monthly fresh water yield analysis of three solar desalination units a comparative study in the south Algeria climatic condition
}

\author{
Houcine Moungar ${ }^{1,2^{*}}$, Ahmed Azzi ${ }^{2}$, Youcef Sahli ${ }^{1}$, Abdelkarim Haida ${ }^{1}$ \\ ${ }^{1}$ Unité de recherche en énergies renouvelables en milieu saharienne (URERMS) Centre de développement des énergies \\ renouvelables (CDER), Adrar 01000, Algérie \\ ${ }^{2}$ Unité de recherche en matériaux et énergies renouvelables (U.R.M.E.R) Université Abou Bekr Belkaïd, Tlemcen 13000, \\ Algérie
}

Corresponding Author Email: houcinemgn@gmail.com

https://doi.org/10.18280/ijht.360423

Received: 22 July 2018

Accepted: 14 September 2018

\section{Keywords:}

solar still, distilled water, shadow, immersed fins, solar irradiation flux

\begin{abstract}
The Purpose of the paper is studied three types solar distillers, double slope with and without immersed fins and the simple solar distiller. A monthly comparative study is investigated experimentally, for a long period of the year. Further, the wind speed influence, the distance between fins, the fins height, the fins number and thickness, on the solar distiller's production, is investigated theoretically. From the obtained results, it is noted that for the wind speed greater than $3.5 \mathrm{~m} / \mathrm{s}$, a decrease in the productivity is caused by the cooling of the outer walls, and this induces some heat losses, especially at the front and rear walls of the solar still. The distance between fins has no significant effect on the still productivity. Moreover, increasing the fins height, from 2 to $5 \mathrm{~cm}$, increase the productivity; however, when the height changes from 6 to $8 \mathrm{~cm}$, the distillate production goes down. A larger fins number lead for rise the produced distilled water amount. Therefore, one should use the maximum number of fins, while taking into consideration the feasibility of the assembly. Increasing the water mass makes the productivity to go down. The obtained results on June 11, 2016, show that the proposed system productivity was about 15 to $27 \%$ higher than that of a simple one, under the following conditions, i.e. $\mathrm{Mw}=42.61 \mathrm{~kg}, \mathrm{~h} 1=3.6 \mathrm{~cm}, \mathrm{Vw}=3.5 \mathrm{~m} / \mathrm{s}, \mathrm{lw}=5 \mathrm{~cm}$ and Nfins $=$ 12. The total annual cost estimation proof clearly that the payback period is less than a years. As well as, it has been found that the increasing lifetime and the interest rate decreasing caused a decrease in the distilled water unit price.
\end{abstract}

\section{INTRODUCTION}

Water is the cheapest and the most expensive is missing, is one of the necessary elements for every living thing on earth life on the earth. The population growth, the economic development, water needs are increasing to response the human live exigency.

These increases are inversely proportional to the resources. Fresh water represents only $3 \%$ from the total amount of water available on earth. Only $1 \%$ of this quantity is usable, the rest is in the glace form or buried underground. Arid regions are characterized by droughts; they are poor in superficial water, which is generally saline. This is the case of some regions in southern Algeria, namely BOUDA, ABADLA, etc.

Hence, these areas have a saline or brackish water usually, withe sunning duration exceeds $14(\mathrm{~h} /$ day) and radiation intensity exceeds $1200\left(\mathrm{w} / \mathrm{m}^{2}\right)$, especially in the summer period. Using the solar desalination process could offer economic, environmental and social benefits for the drinking water supply system in these regions. In the last ten years, several research works have investigated, experimentally and theoretically, the parameters influencing different solar distiller's configurations productivity.

Bechki et al. [1] Studied the effect of shadow of an intermittent partial coverage on the efficiency of a single basin double slope solar still. The daily production in the first series was found equal to $6.01\left(1 / \mathrm{m}^{2} /\right.$ day $)$. This quantity was improved by $33.7 \%$ in the second series. The third one consisted of reducing the temperature of the transparent cover by means of shadows of the intermittent glass cover on the north side. This procedure allowed an additional $12 \%$ improvement in the daily production of distillate Kabeel et al. [2-3] Conducted an experimental and theoretical study on two types of solar stills, namely a conventional inclined solar still and a cascade solar still, which were tested simultaneously. They also examined the influence of the depth and width of the tank on the performance of the solar still. The cascade solar still was supplied with hot water coming from an evacuated tube solar collector. To increase the heat exchange surface, they used a wick on the vertical sides of the cascade distiller. In this case, the daily efficiencies, for one liter of distillate, for the cascade and conventional solar distillers was found to be approximately; 53 and $33.5 \%$, respectively. Conducted a theoretical study on a single basin double slope solar still. The first cover glass, transparent and oriented towards the south, acts as an evaporator; the second one is tinted and oriented towards the north, and acts as a condenser. They added a black dye into the basin of the distiller in order to improve the absorption of the plate and to increase the evaporation surface. Then, they studied the influence of climate and geometric parameters on the productivity of the distiller. They also carried out frequent instantaneous cooling of the transparent 
cover, for example every hour. The efficiency was improved by $55 \%$ compared to that of a single basin still. Belhadj [4] Suggested attaching a condensation cell to a double slope distiller in order to improve the productivity of the system by about $60 \%$, which is higher than that of a conventional distiller or a solar distiller with capillary film. Morad [5] Proposed the periodic cooling of the glazing cover of the distiller. Benhammou Studied the shadow effect of the reflector on the productivity of the distiller [6-16]. Investigated the effect of height, thickness and number of fins on the production of an ordinary distiller; this caused the production of distilled water to increase by $13.7 \%$, compared to a simple distiller [17-20].

Purpose of the paper is studied three types solar distillers; a double slope with and without immersed fins and the simple solar distiller. A monthly comparative study is investigated experimentally, for a long period of the year.

The wind speed, distance between fins, height of fins, number of fins and thickness of the water layer in the basin, influences on the solar still production, is investigated. Hence taking into account the shading effect of vertical surfaces on the productivity of distilled water.

Our result describe for first time the geometrical and meteorological condition influence on the solar still production. Knowing that in ADRAR city, during the summer period the solar radiation intensity reaches its maximum values, it can exceed $1200 \mathrm{~W} / \mathrm{m}^{2}$, as for as the day duration exceed 14 hours. Those conditions automatically favored the solar distiller production. For this reason, we propose the following experiment.

\subsection{Theoretical study thermal balance}

The mathematical model that describes the operation of a solar distiller is based on the thermal balances in each element of the distiller.

\subsubsection{For the double slope solar still}

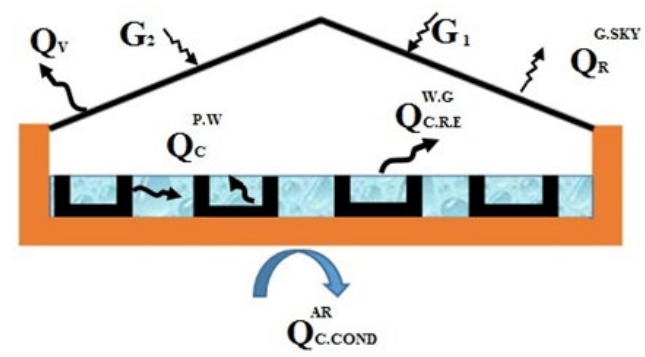

Figure 1. Distillation heat balance

The heat balance on the transparent cover of the distiller is given by the following equation [17, 20-24]:

$m_{g} C p_{g} \frac{d T_{g}}{d t}=\left(1-\tau_{g}\right)\left(G_{1}+G_{2}\right)+\left(h_{c}^{w \_g}+h_{e}^{w}+h_{r}^{w \_g}\right)\left(T_{w}-\right.$

$\left.T_{g}\right)-h_{r}^{g-c e}\left(T_{g}-T_{c e}\right)-h_{v}\left(T_{g}-T_{a}\right)$

The thermal balance in water is expressed as follows:

$$
\begin{aligned}
& m_{w} C p_{w} \frac{d T_{w}}{d t}=\tau_{v} \alpha_{w}\left(\left(G_{1}+G_{2}\right) \frac{A_{\text {eff }}}{A_{p}}+G_{3} \frac{A_{\text {fin }}}{A_{p}}\right)+h_{c}^{p_{w}}\left(T_{w}-\right. \\
& \left.T_{g}\right)-\left(h_{c}^{w_{g}}+h_{e}^{w}+h_{r}^{w_{g}}\right)\left(T_{w}-T_{g}\right)
\end{aligned}
$$

On the absorption plate, the balance is given by the following equation:

$m_{p} C p_{p} \frac{d T_{p}}{d t}=\tau_{v}\left(1-\alpha_{w}\right) \alpha_{p}\left(\left(G_{1}+G_{2}\right) \frac{A_{\text {eff }}}{A_{p}}+G_{3} \frac{A_{f i n}}{A_{p}}\right)-$
$h_{c}^{p_{-} w}\left(T_{w}-T_{g}\right)-\frac{\lambda_{p}}{e_{p}}\left(T_{p}-T_{\text {ins }}\right)$

With $A_{\text {fin }}=2 . N_{\text {fins }}$. H. $l$ and $A_{p}=l_{w} . l$

Calculation of the effective area depends on the determination of the shaded area of a rectangular vertical wall.

$S_{\text {Shaded }}=l * l_{w 0}$

$S_{\text {Shaded }}=l * \frac{H \cos \left(\gamma_{p}-\gamma_{s}\right)}{\tan h}$

$S_{\text {Shaded }}=\frac{S_{f} \cos \left(\gamma_{p}-\gamma_{s}\right)}{\tan h}$

\subsection{For the simple slope solar still}

The heat balance on the transparent cover of the distiller is given by the following equation:

$m_{g} C p_{g} \frac{d T_{g}}{d t}=\left(1-\tau_{g}\right)\left(G_{1}\right)+\left(h_{c}^{w-g}+h_{e}^{w}+h_{r}^{w-g}\right)\left(T_{w}-T_{g}\right)-h_{r}^{g-c e}\left(T_{g}-\right.$ $\left.T_{c e}\right)-h_{v}\left(T_{g}-T_{a}\right)$

The thermal balance in water is expressed as follows:

$m_{w} C p_{w} \frac{d T_{w}}{d t}=\tau_{v} \alpha_{w}\left(G_{1}\right)+h_{c}^{p_{w}}\left(T_{w}-T_{g}\right)-\left(h_{c}^{w_{g}}+h_{e}^{w}+\right.$ $\left.h_{r}^{w_{g}}\right)\left(T_{w}-T_{g}\right)$

On the absorption plate, the balance is given by the following equation:

$m_{p} C p_{p} \frac{d T_{p}}{d t}=\tau_{v}\left(1-\alpha_{w}\right) \alpha_{p}\left(G_{1}\right)-h_{c}^{p_{-} w}\left(T_{w}-T_{g}\right)-\frac{\lambda_{p}}{e_{p}}\left(T_{p}-T_{i n s}\right)$

\section{RESULTS}

Experimental result

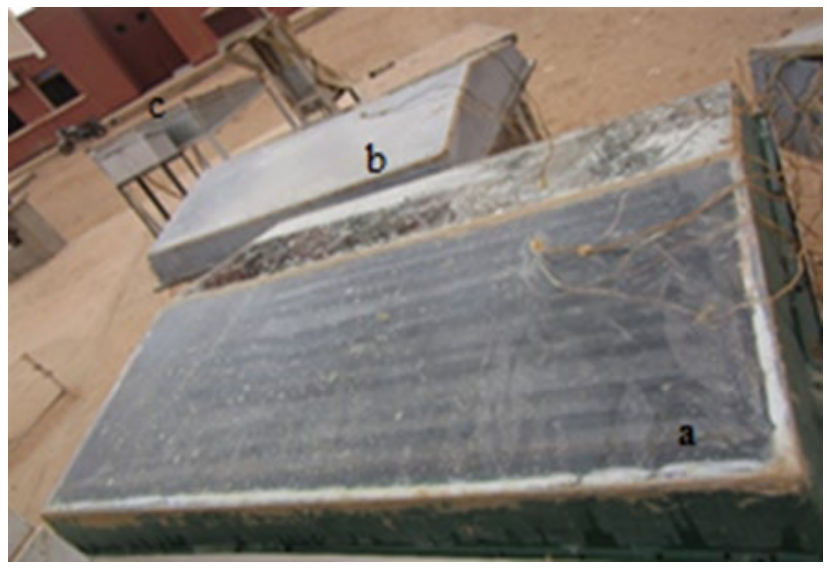

Figure 2. Experimental bench; a) solar still with fins, b) simple solar still, c) single solar still

The present work intends to present an experimental study on a solar hot-box distiller, made of a mixture of glass wool and resin to ensure good thermal insulation. Polyurethane 
foam, $5 \mathrm{~cm}$ thick, was used to reduce thermal losses from rear and side walls. This was done in order to increase the productivity of the distiller and to extend its period of operation during the diurnal period, while taking advantage of the energy stored in the basin.

The temperatures were measured using thermocouples connected to a Fluke 2680 Series data acquisition system. The radiative intensity was measured using a Kipp \& Zonen pyranometer. Various series of tests were carried out during the period extending from March 04, 2015 to August 18, 2015. The temperatures, intensity of the radiative flux and quantity of distillate produced were evaluated. Two glasses dimensions $57 \mathrm{~cm} \mathrm{x} 131 \mathrm{~cm}$, inclined at an angle of $15^{\circ}$, and a basin dimensions $93 \mathrm{~cm} \times 125 \mathrm{~cm}$ were also used; this gives a surface area of $1.16 \mathrm{~m}^{2}$. The tests were carried out on the experimental platform of the Research Unit for Renewable Energies in the Saharan region (URERMS), in ADRAR.

Figure 3 illustrates the evolution of ambient temperature and the intensity of the total horizontal radiative flux for the days of January 20 and July 15. It is noted that the ambient temperature follows the evolution of the solar radiation with a small offset at the maximum value.

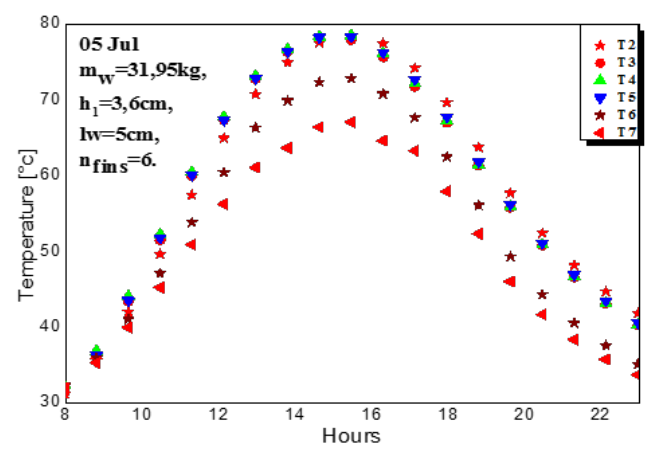

Figure 3. Ambient temperature and intensity of the overall horizontal radiative flux

Figure 4 shows the variation in the temperatures T2, T3, T4, T5, T6 and T7 of the different components in the distiller, namely the temperatures of the basin, horizontal plate, vertical plate, water, inner and outer faces of glass, for the day of July 05. It can clearly be noted that the temperatures follow the evolution of the solar radiation and that the temperature of the plate and that of brine are very close; however, the temperatures of the inner and outer faces of the glazing are significantly lower than that of brine, by 10 to $20{ }^{\circ} \mathrm{C}$. The temperature gradient between glass and brine has a considerable effect on the productivity of the distiller.

It was found that the temperature of the cover glass coincides with the measured temperature of the inner face of this same cover. As for the temperature of brine, according to the results of Figure 5, it can be seen that from 8 a.m. to 1 p.m. the mathematical model describes very well the system, and the curves overlap. In the afternoon, the calculated values are slightly higher than those measured. This discrepancy may be explained by the simplifying assumptions made in the modeling of the system.

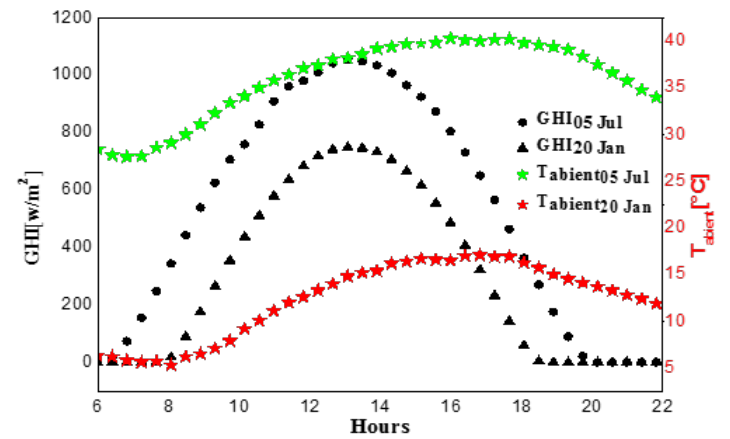

Figure 4. Temperatures of various distiller components

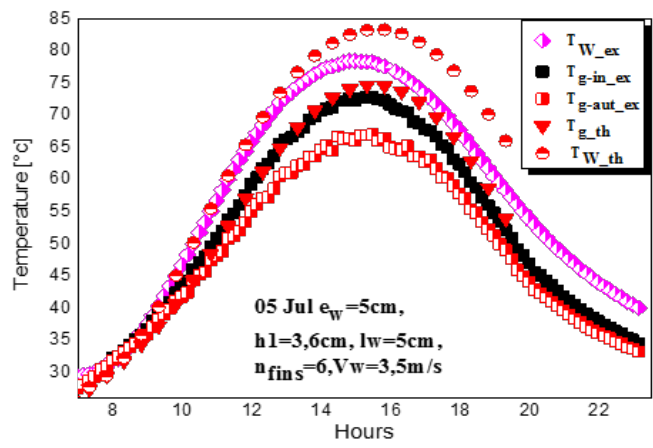

Figure 5. Comparison of theoretical and experimental results

Figure 6 illustrates the production of the distiller for brine thicknesses equal to $2,3,5,6,7$ and $8 \mathrm{~cm}$, corresponding to briny water masses in the basin of $21.3,31.95,42.61,53.26$, $63.92,74.57$ and $85.22 \mathrm{~kg}$, respectively. It was found that increasing the water mass in the basin, from 21.3 to $53.26 \mathrm{~kg}$, causes an increase in the productivity of the distiller. Beyond the mass of $53.26 \mathrm{~kg}$, the opposite effect occurs, i.e. the production decreases.

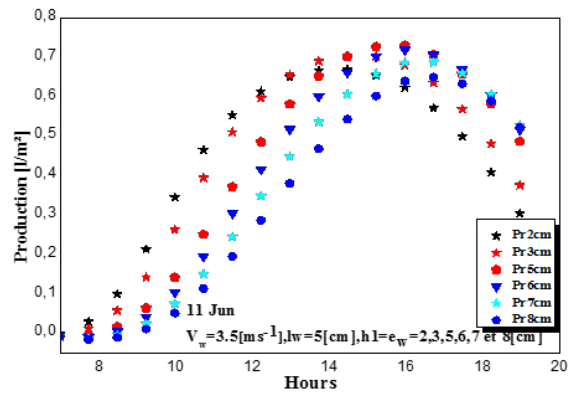

Figure 6. Production of the distiller for different thicknesses of brine

Moreover, an increase in the wind speed beyond $3.5 \mathrm{~m} / \mathrm{s}$ leads a decrease in the production of the distiller. This may be explained by the cooling of the system (Figure 7). 


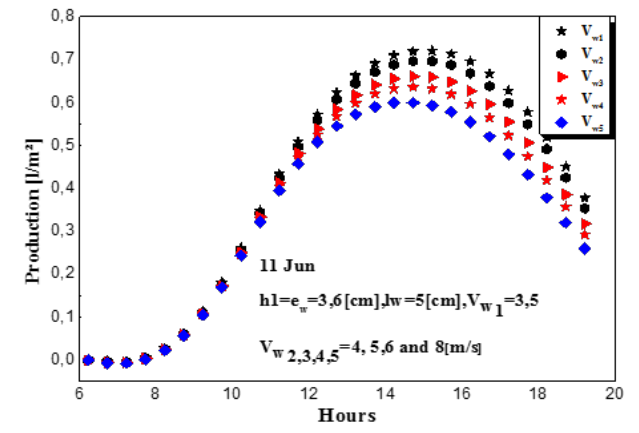

Figure 7. Influence of wind speed on production

Figure 8 depicts the production of the distiller for a distance between fins of 5 and $8 \mathrm{~cm}$. In both cases, the brine thickness varied from 3.6 to $5 \mathrm{~cm}$, for the day of June 11. It was found that the distance between fins does not have a significant effect on the productivity of the distiller.

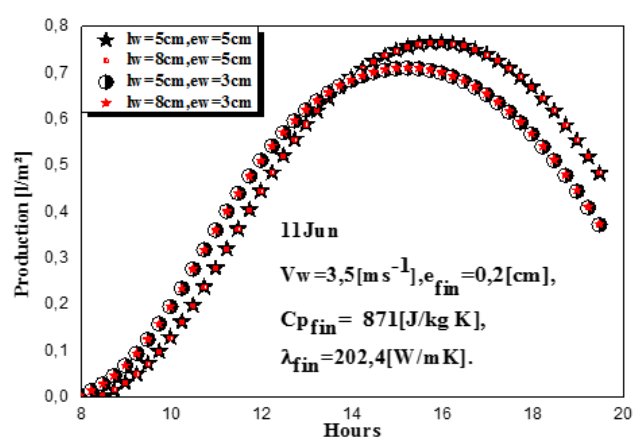

Figure 8. Influence of the distance between fins on production

Increasing the number of fins resulted in a rise in the production of the distiller, and this can be explained by the increase in the heat exchange surface since the absorption plate receives a greater amount of solar energy compared to the case without fins (Figure 9).

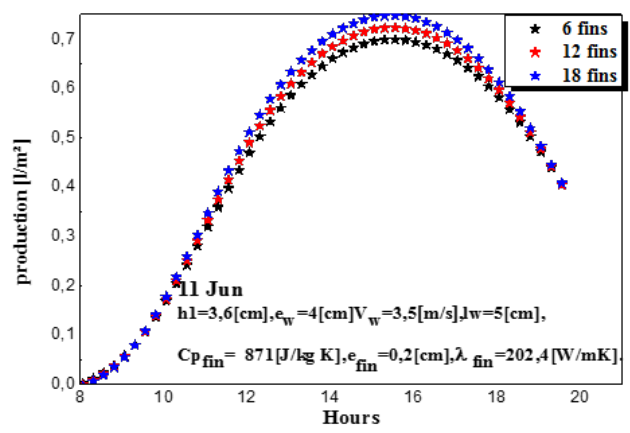

Figure 9. Influence of the number of fins on production.

The entire production of the modified and simple solar still increases with $3 \%$ and $1 \%$ respectively compared to the single slope solar still production. The July production is about 200 $\mathrm{kg}$, as shown in figure 10 .

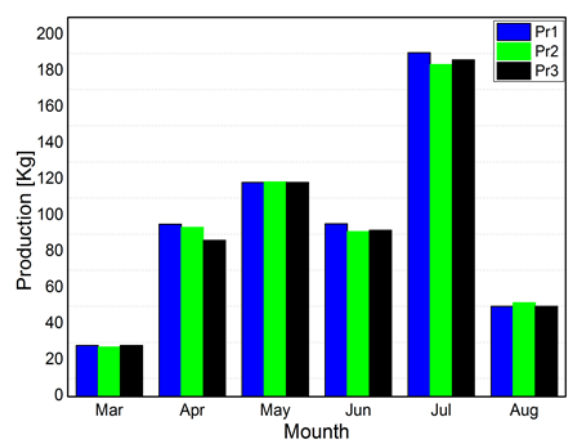

Figure 10. Monthly solar sill's production

\section{COST ESTIMATION}

The total annual cost is estimated at about $55.71 \$$, and costs estimation of the various components is given in Table $1(1 \$=118.25 \mathrm{DZD})$. For example, if the interest rate is $8 \%$ and the system life is 5 years, the annual production is close to $2499.5281 \mathrm{~kg}$, gives a product cost of $0,02 \$$. Knowing that the average latent heat needed to evaporate one kilogram is 0.65 $\mathrm{kWh}$, we will need $1624.7 \mathrm{kWh}$ to produce 2499.5281 kilograms of distilled water. According to the annual cost of $55.71 \$$, the cost of one $\mathrm{kWh}$ will be $0.03 \$ / \mathrm{kWh}$. It has been found that the lifetime increasing and the interest rate decreasing caused a decrease in the unit price. As shown in figure 11 .

Table 1. The various components solar still Cost estimation

\begin{tabular}{ccc} 
Materials & Quantity & \\
\hline Polyurethane foam & 2 & $\$ 42,28$ \\
Silicone adhesive & 3 & $\$ 10,15$ \\
Glass of 3mm & $2 \mathrm{~m}^{2}$ & $\$ 41,57$ \\
Resin & $5 \mathrm{~kg}$ & $\$ 25,37$ \\
Glass wool for the thermal insulation & $2 \mathrm{~m}^{2}$ & $\$ 16,91$ \\
(0.05 m thickness) & & \\
Labour cost (2 workers, 4 day) & & $\$ 81,18$ \\
Total cost & & $\$ 217,46$ \\
Various accessories $10 \%$ & & $\$ 239,75$ \\
The capital cost of the system CC & & $\$ 42,28$
\end{tabular}

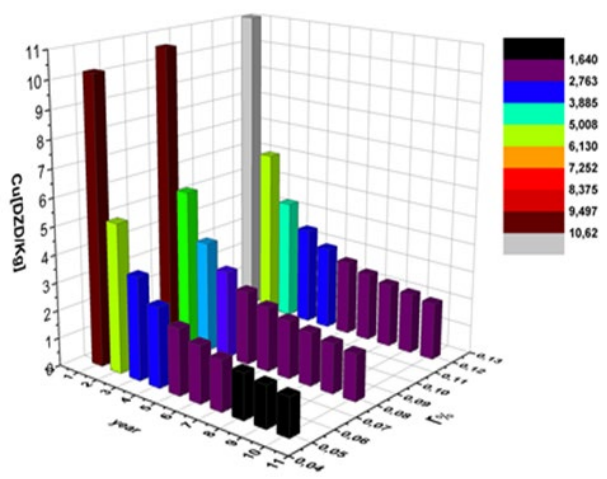

Figure 11. The lifetime and the interest rate influence on the unit price 


\section{CONCLUSION}

The present work presents a theoretical and experimental study of three type's solar distillers, double slope with and without immersed fins and the simple solar distiller. A monthly comparative study is investigated experimentally, for a long period of the year. The influence of wind speed, distance between fins, height of fins, the number of fins and the mass of water in the basin, on the production of the distiller was investigated. The results obtained show that when the wind speed is more than $3.5 \mathrm{~m} / \mathrm{s}$, the productivity of the distiller drops, as the outer walls of the distiller cool more quickly, and this increases the heat losses. It was found that the distance between fins does not have a significant influence on the productivity of the distiller. The fins number increase causes an increase in the distillate quantity. Therefore, it is possible to install the highest fins number. The water mass increase causes a decrease in productivity. For the day of June 11 , and under conditions where $\mathrm{h}_{1}=3.6 \mathrm{~cm}$, Vwind $=3.5 \mathrm{~m} / \mathrm{s}$, lwater $=5 \mathrm{~cm}$, Nfins $=12$ and for a mass of water of mwater $=21.3,31.95,42.61,53.26,85.22 \mathrm{~kg}$, the production of the distiller, with immersed fins, increased by 21, 25, 27, 27 and $15 \%$, respectively, compared to that of a conventional distiller. The estimated cost per $\mathrm{kg}$ of distillate was between $0.9 \$$ for the first year and $0.01 \$$ for ten year lifetimes.

The best available estimate of the measured values of the daily distiller production from the month of March to August is fond that the average $=6,616 \mathrm{Kg}$. The variance of the values due to random variations is; variance $=2.311 \mathrm{Kg}^{2}$. The experimental standard deviation; standard deviation $=1.52 \mathrm{Kg}$. The experimental standard deviation of the mean; variance of mean $=0.027 \mathrm{Kg}^{2}$. In addition, a standard uncertainty $=0.165$ $\mathrm{Kg}$. And the relative standard uncertainty $=0.025$.

Table 2. Measurements accuracy range

\begin{tabular}{cccc} 
No. & Instrument & Accuracy & Range \\
\hline 1. & Thermocouple $\mathrm{J}$ & $\pm 0.0102{ }^{\circ} \mathrm{C}$ & $-30-150^{\circ} \mathrm{C}$ \\
2. & Kipp-Zonen & \pm 0.05 & $0-5000 \mathrm{~W} / \mathrm{m}^{2}$ \\
& solarimeter & $\mathrm{W} / \mathrm{m}^{2}$ & \\
3. & Measuring beaker & $\pm 0.05 \mathrm{ml}$ & $0-3000 \mathrm{ml}$ \\
4. & acquisition Fluke 2680 & $\pm 0.2 \mathrm{mV}$ & $300 \mathrm{mV} 0^{\circ} \mathrm{c}$ to \\
& & & $60^{\circ} \mathrm{c}$
\end{tabular}

\section{ACKNOWLEDGMENTS}

The present work was supported by the solar distillation laboratory at the Thermal and Thermodynamics Conversion Division, within the Research Unit Energies in Renewable Energies in the Sahara Medium. Development Centre of Renewable Energies, Adrar, Algeria.

Authors would like to extend his thanks to URERMS for its support in implementing the project

\section{REFERENCES}

[1] Bechki D, Bouguettaia H, Blanco GJ, Babay S, Bouchekima B, Boughali S, Mahcene H. (2010). Effect of partial intermittent shading on the performance of a simple basin solarstill in south Algeria. Desalination 260: 65-69. https://doi.org/10.1016/j.desal.2010.04.066

[2] Kabeel AE, Khalil A, Omara ZM, Younes MM. (2012). Theoretical and experimental parametric study of modified stepped solar still. Desalination 289: 12-20. https://doi.org/10.1016/j.desal.2011.12.023

[3] Kabeel AE, Omara ZM, Essa FA. (2014). Enhancement of modified solar still integrated with external condenser using nanofluids: An experimental approach. Energy Convers. Manag 78: 493-498.

[4] Belhadj MM, Bouguettaia H, Marif Y, Zerrouki M. (2015). Numerical study of a double-slope solar still coupled with capillary film condenser in south Algeria. Energy Convers. Manag 94: 245-252

[5] Morad MM, El-Maghawry HAM, Wasfy KI. (2015). Improving the double slope solar still performance by using flat-plate solar collector and cooling glass cover. Desalination 373: 1-9.

[6] Mohammed B, Houcine M. (2013). Revue internationale D'héliotechnique. Effet Des Paramètres Géométriques d'un Réflecteur Plan Vertical Sur Les Performances d'un Distillateur Solaire Mono-Incline Couple A Un Condenseur Séparé 45: 14-20.

[7] Okeke CE, Egarievwe SU, Anmalu AOE. (1990). Effects of coal and charcoal on solar-still performance. Enqy 15(11): 1071-1073. https://doi.org/10.1016/03605442(90)90035-z

[8] Cooper PI. (1969). Digital simulation of transient solar still processes. Solar Energy 12: 313-331. https://doi.org/10.1016/0038-092x(69)90046-2

[9] El-Sebaii AA, Ramadan MRI, Aboul-Enein S, El-Naggar M. (2015). Effect of fin parameters on single basin solar still performance. Desalination 365: 15-24.

[10] Rubio E., Fernández JL, Porta-Gándara MA. (2002). Modeling thermal asymmetries in double slope solar stills. Renew Energy 29(6): 895-906.

[11] Al-Hinai H, Al-Nassri MS, Jubran BA. (2002). Effect of climatic, design and operational parameters on the yield of a simple solar still. Energy Conversion and Management 43(13): 1639-1650. https://doi.org/10.1016/S0196-8904(01)00120-0

[12] Hassan ESF, Hosny HM. (2002). Thermal performance of a single-sloped basin still with an inherent built-in additional condenser. Desalination 142: 19-27. https://doi.org/10.1016/s0011-9164(01)00422-2

[13] Al-Hayeka I, Badran O. (2004). The effect of using different designs of solar stills on water distillation. Desalination 169(2): 121-127.

[14] Voropoulos K, Mathioulakis E, Belessiotis V. (2004). A hybrid solar desalination and water heating system. Desalination 164(2): 189-195. https://doi.org/10.1016/s0011-9164(04)00177-8

[15] Dev R, Tiwari GN. (2011). Characteristic equation of the inverted absorber solar still. Desalination 269: 67-77.

[16] Tanaka H, Nakatake Y. (2005). A simple and highly productive solar still: A vertical multiple-effect diffusion-type solar still coupled with a flat-plate mirror. Desalination 173(3): 287-300.

[17] Moungar H, Azzi A, Sahli Y, Hieda A. (2018). Double slope solar still with immersed fins: Theoretical and experimental study. U.P.B. Sci. Bull, Series C 80(1): 2286-3540.

[18] Shukla SK. (2007). Computer modeling of double slope solar still by using inner glass cover temperature. ISES Sol. World Congr 3: 2189-2200. https://doi.org/10.1007/978-3-540-75997-3_443

[19] Arabi MA, Zurigat Y, Al-Hinai H, Al-Hiddābi S. (2002). Modeling and performance analysis of a solar 
desalination unit with double-glass cover cooling. Desalination 143(2): 173-182. https://doi.org/10.1016/s0011-9164(02)00238-2

[20] El-Sebaii AA. (2000). Effect of wind speed on some designs of solar stills. Energy Convers. Manag. 41(6): 523-538.

[21] Moungar H, Azzi A, Sahli Y, Hieda A. (2017). Immersed fins influence on the double slope solar still production in south algeria climatic condition. Nternational Journal of Heat and Technology 35. http://dx.doi.org/10.18280/ijht.350444

[22] Sathyamurthy R, Nagarajan PK, Edwin M, Madhu B, ElAgouz SA, Ahsan A, Mageshbabu D. (2016). Experimental investigations on conventional solar still with sand heat energy storage. International Journal of Heat and Technology 34(4): 597-603. https://doi.org/10.18280/ijht.340407

[23] Mesmoudi K, Meguellati K, Bournet PE. (2017). Thermal analysis of greenhouses installed under semi arid climate. International Journal of Heat and Technology 35(1): https://doi.org/10.18280/ijht.350304

[24] Komolafe CA, Waheed MA. (2018). Design and fabrication of a forced convection solar dryer integrated with heat storage materials. ACSM 42(1): 23-39. https://doi.org/10.3166/acsm.42.23-39

\section{NOMENCLATURE}

$\Upsilon \mathrm{p}$

Ys

G1

G2

\section{Subscripts}

$\begin{array}{ll}\text { w } & \text { Water } \\ \mathrm{g} & \text { Glass } \\ \mathrm{p} & \text { Plate }\end{array}$

Plate
Azimuthal angle of the plane

Solar azimuth

Radiation received by a $15^{\circ}$ inclined plane facing the south

Radiation received by a $15^{\circ}$ inclined plane facing the north 